\title{
PERBEDAAN PENGARUH KOORDINASI MATA-KAKI DAN METODE PEMBELAJARAN TERHADAP KEMAMPUAN SERVIS ATAS SEPAK TAKRAW PADA MAHASISWA PKO FIK UNIMED
}

\author{
Ibrahim Wiyaka ${ }^{1}$, M Nustan Hasibuan ${ }^{2}$, Pangondian Purba ${ }^{3}$ \\ Fakultas Ilmu Keolahragaan, Universitas Negeri Medan \\ ibrahimwiyaka10@gmail.com
}

\begin{abstract}
Abstrak : Servis selain merupakan sepakan awal untuk memulai permainan juga merpakan serangan awal untuk mencari angka kemenangan, terkadang suatu regu kalah bukan karena permainannya kurang baik akan tetapi servis yang dilakukan tidak mematikan, mudah diambil oleh lawan dan sangkut di net serta bola keluar. Kenyataan inilah yang dialami oleh para mahasiswa sehingga sangat diperlukan suatu cara untuk meningkatkannya. Salah salah yang dapat dilakukan adalah mengadakan penelitian dengan judul "Perbedaan Pengaruh Koordinasi Mata-Kaki dan Metode Pembelajaran terhadap Kemampuan Servis Atas pada Mahasiswa PKO FIK Unimed Tahun 2017. Tujuan penelitian ini adalah untuk mengetahui (1). Perbedaan pengaruh antara koordinasi mata-kaki tinggi dan koordinasi mata-kaki rendah terhadap hasil servis atas sepak takraw (2) Perbedaan Pengaruh metode pembelajaran servis bola digantung dan dibuang terhadap servis atas sepak takraw.(3) Mengetahui ada tidaknya interaksi antara koordinasi mata-kaki dengan metode pembelajaran servis atas sepak takraw. Penelitian menggunakan metode eksperimen. Rancangan penelitian dengan Faktorial $2 \times 2$. populasi penelitian ini adalah seluruh mahasiswa PKO FIK Unimed yang ikut mata kuliah sepak takraw lanjutan sebanyak 112 orang. Sampel sebanyak 72 orang yang diambil dengan teknik purposive sampling. Instrument penelitian menggunakan tes koordinasi matakaki dan tes servis. Teknik analisis data menggunakan analisis statistik sedangkan perhitungannya menggunakan uji perbedaan dengan Anova eksperimen Faktorial 2 x 2 pada taraf signifikan 5\%. untuk memenuhi asumsi hasil penelitian dilakukan uji reliabilitas dan uji prasarat analisis. Hasil penelitian meninjukkan (1). Terdapat perbedaan pengaruh koordinasi mata-kaki tinggi dan koordinasi mata-kaki rendah terhadap kemampuan servis atas sepak takraw $-\mathrm{p} 0,000<\mathrm{a} 0,05,(2)$. Terdapat perbedaan pengaruh antara bola digantung dengan bola dibuang terhadap kemampuan servis atas sepak takraw. - p 0,006 < a 0,05, dan, (3). Terdapat Interaksi antara koordinasi mata-kaki dengan kemampuan servis atas sepak takraw. - p 0,009 $<0,056$. Nilai adjustd $\mathrm{R}$ Square sebesar 0,080 artinya bahwa terdapat interaksi sebesar $8 \%$.
\end{abstract}

Kata Kunci : Koordinasi Mata-Kaki, Metode Pembelajaran, Servis Atas

\section{PENDAHULUAN}

Untuk bermain sepak takraw dengan baik haruslah seseorang mempunyai kemampuan atau keterampilan yang baik. Kamampuan yang penting dan sangat perlu dimiliki oleh seorang pemain sepak takraw adalah kemampuan dasar bermain sepak takraw. Kemampuan dimaksud adalah menyepak dengan bahagian-bahagian kaki, memainkan bola dengan kepala (main kepala), memainkan bola dengan dada, memainkan bola dengan paha, memainkan bola dengan bahu. (Ratinus Darwis 1992:15).

Kemampuan dasar di atas itu antara satu dengan yang lainnya merupakan suatu kesatuan yang tidak bisa dipisahkan." Selain itu, pemain sepak takrtaw juga harus bisa menguasai teknik teknik dasar dan keterampilan khusus seperti servis, mengumpan, smash, dan blok (menahan).
Dari sekian banyak teknik dasar dalam permainan sepak takraw, maka dalam penelitain ini hanya mengkaji masalah teknik dasar servis atas karena teknik ini sulit dilakukan dengan baik oleh para mahasiswa. Padahal servis merupakan sepakan awal untuk memulai permainan. Bukan hanya itu, servis juga menjadi suatu senjata serangan awal dari suatu regu ke regu lawan, inilah menyebabkan teknik ini menjadi salah satu teknik terpenting. Muhammad Suhud (1991:20), menyatakan bahwa ; " Servis itu suatu teknik penyajian bola pertama dalam permainan sepak takraw .Penguasaan teknik servis sangat penting mengingat: "Dengan servis suatu regu dapat menghasilkan angka, dengan servis suatu regu dapat memimpin pertandingan sesuai dengan tipe dari yang dikehendaki regu yang servis, servis merupakan serangan pertama terhadap regu lawan" 
Untuk dapat melakukan servis yang baik diperlukan sikap permulaan yang benar, baik dan keseimbangan tubuh yang terjaga, koordinasi yang baik dan sikap permulaan yang benar akan mengahasilkan servis yang baik.

Koordinasi merupakan kemampuan biomotorik yang sangat kompleks. Koordinasi erat hubunganya dengan kecepatan, kekuatan, daya tahan dan fleksibilitas, sehingga sangat dibutuhkan hampir setiap cabang olahraga, perlunya koordinasi dalam olahraga juga melatih kemampuan motorik atlet untuk selalu bergerak sesuai dengan apa yang diperintahkan. Oleh karena itu koordinasi selalu terkait dengan biomotor yang lain, yaitu kelincahan dan ketangkasan ( Crespo, Milley, and Bornemann, et al,. dalam Sukadiyanto, 2002 : 139 ). Selanjutnya mengenai indicator koordinasi, Sukadiyanto ( 2002 : 139 ), menyatakan bahwa indicator utama koordinasi adalah ketepatan dan gerak yang ekonomis.

Berdasarkan pendapat di atas, disimpulkan bahwa koordinasi merupakan suatu kemapuan untuk mengkombinasikan beberapa gerakan tanpa ketegangan, dengan urutan yang benar yang dilakukan secara lancar tanpa penggunaan energi yang berlebihan. Sehingga koordinasi sangat bermanfaat dan mempunyai peranan penting dalam melaksanakan servis atas dalam permainan sepak takraw.

Untuk menghasilkan sepakan servis yang lebih baik perlu dikoordinasikan antara gerakan kaki dengan visual. Koordinasi mata kaki pada waktu melakukan sepakan servis merupakan suatu kemampuan di dalam memadukan persepsi visual dengan gerakan kaki ke dalam satu pola gerak khusus, yaitu menyepak obyek sasaran berupa bola. Seorang pemain yang tidak memiliki tingkat koordinasi yang baik tidak akan menghasilkan kualitas sepakan yang baik dan menguntungkan dalam suatu permainan.

Obyek yang digunakan berupa bola adalah obyek yang bergerak, pemain pada waktu menyepak bola dalam keadaan bergerak aktif, sehingga pemain yang melakukan servis tingkat kesulitannya tinggi namun harus dengan ketepatan sepakan yang relatif tinggi, sehingga pemain harus pandai-pandai mengkombinasikan antara persepsi visual, gerakan kaki dan perasaan gerak. Apabila di dalam mengkombinasikan beberapa gerakan kurang berhasil, maka servis yang dilakukan hasilnya juga kurang memuaskan.

Sepak mula atau servis memang awalnya merupakan teknik dasar pembuka permainan atau pertandingan. Namun pada saat ini pada permainan tingkat tinggi, sepak mula (servis) merupakan serangan pertama yang penting dalam memperoleh angka kemenangan dalam suatu pertandingan. Kesalahan atau kegagalan regu dalam melakukan servis akan memberi angka bagi regu lawan. Tekong hendaknya dapat membuat servis yang baik dan dapat mengarahkan servis kesasaran yang lemah dari lawan sehingga lawan sulit untuk menerima dan mengontrol bola yang mengarah ke daerah pertahanannya. Menurut Wiyaka (2017: 61 ) Teknik sepak mula (servis) ditinjau dari posisi kaki pukul terhadap bola dibagi menmjadi dua cara, yaitu : Servis bawah dan servis atas.

\section{1). Servis Bawah}

Teknik melakukan sepak mula (servis) Bawah, yaitu : (a). Berdiri dengan salah satu kaki berada di dalam lingkaran sebagai kaki tumpu, kaki lainnya berada di samping belakang badan sebagai awalan. Kaki tumpu diusahakan menghadap ke arah pelambung. (b). Salah satu lengan menunjukkan permintaan bola yang akan dibuangkan oleh apit sebagai pelambung. (c). Saat bola datang, kaki pukul diayun dari bawah ke atas menyongsong datangnya bola. Perkenaan dengan bola adalah pada kaki bagian dalam dikencangkan. (d). Bola ditendang saat ketinggian bola setinggi lutut. (e). Berusaha bola dipukul melewati atas net. (f). Setelah melakukan sepakan, badan melakukan gerak lanjutan dengan mengikuti arah gerak sepakan dan mendarat dengan mengeper.

Kesalahan Umum dalam Melakukan Servis Bawah, antara lain: (1) Kaki tumpu tidak dihadapkan ke pelambung, sehingga pada saat pukulan bola gerak lanjutannya terhambat (tidak anatomis). (2) Kaki pukul tidak dikeraskan pada pergelangan kaki, akibatnya pukulan bola tidak bertenaga, dan tidak dapat diarahkan sesuai harapan. (3) Kaki tumpu atau kaki pukul menginjak garis, hal ini merupakan kesalahan dalam peraturan permainan.

\section{2). Sevis Atas}

Teknik melakukan sepak mula (servis) atas, yaitu: (a) Awalan dilakukan seperti servis bawah, pemain yang akan melakukan servis berdiri dengan salah satu kaki tumpu berada di dalam lingkran. Kaki lainnya sebagai awalan berada di luar lingkaran di belakang badan. Salah satu lengan diangkat lurus sejajar dengan permintaan bola yang akan dibuangkan oleh salah satu apit (pelambung). (b) Saat bola mencapai titik ketinggian yang diiginkan, kaki pukul diayunkan ke arah bola dibantu dengan kaki tumpu jinjit. Pukulan dilakukan eksplosif di atas kepala, sehingga pukulan menukik tajam ke lapangan lawan. (c) Pada saat pukulan, perkenaan kaki dengan bola dapat dilakukan dengan kaki bagian dalam, punggung kaki atau telapak kaki (tapak). (d) Hendaknya jangkauan kaki dioptimalkan dengan meluruskan kaki tumpu dan kaki pukul sebagai kesatuan, sehingga bola dapat dipukul dengan jangkauan yang lebih tinggi, akibatnya bola akan lebih tajam masuk ke daerah lapangan permainan lawan. (e) Saat perkenaan bola, posisi kaki pukul harus berada di atas bola, agar bola dapat dipul tajam menukik. (f) Setelah melakukan sepakan, 
badan mengikuti gerak lanjutan tungkai, dan kaki mendarat dengan mengeper.

Adapun kesalahan umum dalam Melakukan servis atas, antara lain : (1). Kaki tumpu tidak dihadapkan ke pelambung, sehingga pada saat pukulan bola gerak lanjutannya terhambat (tidak anatomis). (2). Kaki pukul tidak dikeraskan pada pergelangan kaki, akibatnya pukulan bola tidak bertenaga, dan tidak dapat diarahkan sesuai harapan. (3). Saat memukul bola, kaki pukul tidak di atas bola, akibatnya bola datar tidak tajam menukik .

Berdasarkan kajian di atas peneliti memilih pembelajaran sepak mula (servis) dengan bola digantung dan bola dibuang sendiri.

\section{a) Metode Pembelajaran Servis Atas Dengan Bola Digantung}

Pembelajaran servis atas menggunakan bola digantung yaitu kegiatan pembelajaran menyepak bola menggunakan teknik sepak kuda, bola digantung menggunakan tali. Pembelajaran bertujuan untuk meningkatkan kemampuan servis atas dengan sepak kuda. Pelaksanaan pembelajaran servis atas bola digantung pada penelitian ini adalah sebagai berikut : (1). Bola digantung dengan tali, (2). Tinggi bola yang digantung setinggi jangkauan tangan pemain, (3). Tinggi gantungan antara 2,5 m $-3 \mathrm{~m}$ dari tinggi pemain, (4). Pemain berdiri dekat atau di bawah bola, dengan posisi siap melakukan gerakan servis atas, (5). Bola yang disepak/servis dalam keadaan diam tak bergerak, (6). Arah sepakan harus kedepan paling rendah sejajar kepala bagian atas.

Dengan adanya tali, maka tingkat komplektifitas dapat dikurangi. Tali yang digunakan sebagai pengendali bola agar tidak bergerak kemanamana dan ketinggian bola tetap. Ruang gerak lebih terbatas, sehingga kontrol bola lebih ketat dan mahasiswa tidak kesulitan dalam melakukan sepakan. Berdasarkan pelaksanaannya, dapat dianalisa mengenai keuntungan dan kekurangan pembelajaran servis atas dengan bola digantung. Keuntungan pembelajaran servis atas dengan bola digantung, yaitu: (1). Efisien tenaga, karena adanya tali untuk menggantung, maka bola diam dan tidak bergerak kemana-mana, (2). Frekuensi pelaksanaan servis lebih banyak, ajeg dan tepat, sehingga akan menguntungkan dalam pembentukan teknik servis atas.

Selan keuntungan terdapat pula kekurangan pembelajaran servis bola digantung, antara lain: (1). Arah gerak bola dipengaruhi oleh panjang pendeknya tali dan daerah perkenaan kaki dan bola, (2). Gerak lambat (mahasiswa hanya berdiri dibawah bola sebab bola diikat tali).

\section{b) Pembelajaran Servis Atas Bola Dibuang Sendiri}

Pembelajaran servis atas bola dibuang sendiri yaitu kegiatan pembelajaran menyepak bola dengan teknik sepak kuda. Hal ini diterapkan untuk meningkatkan kemampuan servis atas. Cara melaksanakan pembelajaran servis atas dengan bola dibuang sendiri adalah sebagai berikut : (1). Berdiri dengan kaki dibuka selebar bahu, bola dipegang sendiri, ( 2). Kaki tumpu sedikit ditekuk, (3). Bola dibuang ke atas dan disepak dengan punggung kaki (sepak kuda), (4). Badan tegak, dan berputar mengikuti arah pukulan untuk menjaga keseimbangan, (5). Pandangan mata pada bola, (6). Pergelangan kaki sepak pada saat menyepak bola ditegangkan atau dikeraskan, (7). Arah sepakan dapa t diubah - ubah kekanan - kekiri atau sesuai perkenaan kaki dengan bola.

Pembelajaran servis dengan bola dibuang sendiri memiliki keuntungan dan kekurangan. Berdasarkan pelaksanaannya, dapat dianalisis mengenai keuntungan dan kekurangan servis atas dengan bola dibuang sendiri sebagai berikut. Keuntungan servis atas bola dibuang sendiri : (a) Lambungan bola lebih bebas sesuai keinginan (karena tidak ada tali) sehingga mahasiswa terbiasa dengan bola lambungan, (b). Bola dapat di sepak sesuai kemampuan (tinggi rendahnya), (c). Selain melatih keterampilan servis atas juga melatih kecepatan reaksi, karena kalau tidak disepak maka bola akan jatuh.

Kekurangan pembelajaran servis atas dengan bola dibuang sendiri : (a). Bagi pemula sulit melakukan lemparan dan timing yang tepat sehingga memerlukan tenaga ekstra, (b). Dengan seringnya mengambil bola sendiri akan menambah tenaga sehingga lebih melelahkan, (c). Bagi pemula sering perkenaan bola dengan kaki tidak pas, yaitu punggung kaki.

Kemampuan servis atas sepak takraw akan dipengaruhi oleh tingkat koordinasi mata-kaki dan itu dapat dilatih dengan metode bola digantung dan bola dibuang sendiri. Bertitik tolak pada uraian tersebut maka ditarik hipotesis sebagai berikut : (1) Terdapat perbedaan pengaruh antara koordinasi mata-kaki tinggi dan koordinasi mata-kaki rendah terhadap kemampuan servis atas dalam permainan sepak takraw, (2) Terdapat perbedaan pengaruh pembelajaran servis bola digantung dan bola dibuang sendiri terhadap kemampuan servis atas dalam permainan sepak takraw, (3) Terdapat interaksi antara metode pembelajaran servis atas sepak takraw dengan koordinasi mata-kaki.

\section{METODE}

Metode yang digunakan dalam penelitian ini adalah metode eksperimen. Dalam penelitian ini terdapat dua kelompok eksperimen dengan diberikan perlakuan yang berbeda. Kelompok pertama diberikan pembelajaran servis dengan bola di 
gantung, sedangkan kelompok yang kedua diberi pembelajaran servis dengan bola dibuang sendiri. Perbedaan hasil pembelajaran dapat diketahui dengan mengadakan pengetesan kedua kelompok dengan tes servis.

Populasi dalam penelitian ini adalah seluruh mahasiswa yang sedang mengambil mata kuliah sepak takraw lanjutan yang berjumlah 112 orang. Sampel dalam penelitian ini adalah sebanyak 72 mahasiswa yang diambil dengan teknik purpossive sampling dengan kriteria sampel bukan atlet sepak takraw. Sampel mengikuti latihan 2 kali seminggu selama 3 bulan (18 kali pertemuan).

Instrument penelitian digunakan untuk mengukur atau mengetahui gejala-gejala dan sifatsifat variable yang diteliti. Yang penting bahwa instrumen harus memenuhi criteria sebagai instrument yang baik. Sugiyanto (1993:66), menyatakan bahwa," Instrumen pengukuran dikatakan baik apabila memenuhi kriteria : instrument pengukuran harus valid, reliable, mudah di administrasikan dan ada norma penilaiannya".

Teknik pengumpulan data dalam penelitian ini dengan cara mengadakan pengetesan terhadap variable penelitian. Tes yang digunakan adalah : 1 . Tes Koordinasi Mata-Kaki, dan 2. Tes Keterampilan Servis.

\section{HASIL DAN PEMBAHASAN}

Deskripsi hasil analisis data kemampuan servis atas sepak takraw pada kegiatan perkuliahan pada mahasuswa PKO-FIK Unimed tahun 2017/2017 sesuai dengan kelompok disajikan dalam bentuk tabel sebagai berikut :

Tabel 1. Ringkasan Angka-Angka Statistik Deskriptif Data Kemampuan Servis Sepak Takraw Menurut Kelompok Penelitian.

\begin{tabular}{|c|c|c|c|c|c|}
\hline Perlakuan & $\begin{array}{l}\text { Koordinasi } \\
\text { Mata-Kaki }\end{array}$ & Statistik & $\begin{array}{c}\text { Tes } \\
\text { Awal }\end{array}$ & $\begin{array}{c}\text { Tes } \\
\text { Akhir }\end{array}$ & Peningkatan \\
\hline \multirow{6}{*}{$\begin{array}{l}\text { Metode Bola } \\
\text { Digantung } \\
\text { (Al) }\end{array}$} & \multirow{3}{*}{$\begin{array}{l}\text { Tinggi } \\
\text { (B1) }\end{array}$} & Jumlah & 89 & 118 & 29 \\
\hline & & Mean & 4.94 & 6.55 & 1.61 \\
\hline & & SD & 2.48 & 2.52 & \\
\hline & \multirow{3}{*}{$\begin{array}{l}\text { Rendah } \\
\text { ( B2) }\end{array}$} & Jumlah & 61 & 78 & 17 \\
\hline & & Mean & 4.38 & 4.33 & 0.05 \\
\hline & & SD & 2.06 & 1.49 & \\
\hline \multirow{6}{*}{ Metode Bola } & \multirow{3}{*}{$\begin{array}{l}\text { Tinggi } \\
\text { (B1) }\end{array}$} & Jumlah & 66 & 109 & 43 \\
\hline & & Mean & 3.66 & 6.05 & 2.39 \\
\hline & & SD & 2.24 & 1.78 & \\
\hline & \multirow{3}{*}{$\begin{array}{c}\text { Rendah } \\
\text { (B2) }\end{array}$} & Jumlah & 84 & 126 & 42 \\
\hline & & Mean & 4.66 & 7 & 2.34 \\
\hline & & SD & 2.24 & 1.74 & \\
\hline
\end{tabular}


Tabel 2 : Rangkuman Hasil Uji Normalitas Data

\begin{tabular}{|c|c|c|c|c|c|}
\hline Kelompok & N & Prob & L hitung & Lt abel & Kesimpulan \\
\hline $\begin{array}{c}\text { Bola Gantung } \\
\text { Tinggi }\end{array}$ & 18 & 0.05 & 0.126 & 0.200 & Distribusi normal \\
\hline $\begin{array}{c}\text { Bola Gantung } \\
\text { Rendah }\end{array}$ & 18 & 0.05 & 0.171 & 0.200 & Distribusi normal \\
\hline $\begin{array}{c}\text { Bola Buang } \\
\text { Tinggi }\end{array}$ & 18 & 0.05 & 0.155 & 0.200 & Distribusi normal \\
\hline $\begin{array}{c}\text { Bola Buang } \\
\text { Rendah }\end{array}$ & 18 & 0.05 & 0.172 & 0.200 & Distribusi normal \\
\hline
\end{tabular}

Tabel 3. Rangkuman Hasil Uji Homogenitas Data

\begin{tabular}{|c|c|c|c|c|}
\hline Kelompok & $\mathbf{N}$ & $\mathbf{S D}^{2}$ & F hitung & Ft \\
\hline Pree-test & 72 & 7.9524 & 1.786 & 3.13 \\
\hline Post-test & 72 & 1.9600 & 2.631 & 3.13 \\
\hline
\end{tabular}

Berdasarkan deskripsi data metode pembelajaran bola digantung dan metode pembelajaran bola dibuang serta tingkat koordinasi mata-kaki tinggi dan koordinasi mata-kaki rendah menunjukkan: (1) Bila dibandingkan antara kelompok siswa yang mendapat perlakuan pembelajaran servis sepak takraw dengan metode bola digantung dan bola dibuang, maka dapat diketahui bahwa kelompok pembelajaran servis sepak takraw dengan metode bola dibuang sendiri rata-rata peningkatannya lebih besar 1.1 daripada kelompok pembelajaran servis sepak takraw dengan metode digantung. (2) Bila dibandingkan antara kelompok siswa yang memiliki koordinasi mata-kaki tinggi dan yang memiliki koordinasi mata-kaki rendah, diketahui bahwa kelompok siswa yang memiliki koordinasi mata-kaki tinggi sebesar 0,35 lebih besar dari kelompok siswa yang memiliki koordinasi mata-kaki rendah.

\section{Persyaratan Uji Analisis}

\section{1) Uji Normalitas}

Tujuan uji normalitas adalah untuk mengetahui apakah data yang diperoleh dari tiap-tiap variabel yang dianalisis sebenarnya mengikuti pola sebaran normal atau tidak. Pengujian normalitas dalam penelitian ini menggunakan kolmogorovSmirnov. Hasil perhitungan dapat dilihat pada tabel 2.
Berdasarkan tabel 2 di atas dapat diketahui L hitung < L tabel. Hal ini menunjukkan bahwa sampel yang diambil berasal dari populasi yang berdistribusi normal.

\section{2) Uji Homogenitas}

Uji homogenitas dimaksudkan untuk mengetahui kesamaan varians dari kedua kelompok. Jika kedua kelompok tersebut memiliki kesamaan varians, maka apabila nantinya kedua kelompok memiliki perbedaan, maka perbedaan tersebut disebabkan oleh perbedaan rata-rata kemampuan. Hasil uji homogenitas data antara kelompok 1 (K1 ) dan kelompok 2 (K2) dapat dilihat pada tabel 3.

Dari hasil uji homogenitas yang dilakukan diperoleh nilai Fitung $=1.786$. Sedangkan angka $F_{t}$ $=3.13$. Ternyata nilai Fhitung 2.631 lebih kecil dari $F_{t}=3.13$. Karena $F_{\text {hitung }}<F_{\text {tabel }}$ maka hipotesis nol diterima. Dengan demikian dapat disimpulkan bahwa sampel penelitian memiliki varians yang homogen.

\section{3) Uji Hipotesis}

Adapun pengujian hipotesis yang dilakukan, yaitu: (1) Perbedaan Pengaruh Koordinasi Mata-Kaki Tinggi dan Koordinasi Mata - Kaki Rendah Terhadap Kemampuan Servis Atas Sepak Takraw. Berdasarkan hasil perhitungan diperoleh $-\mathrm{p} 0,000$ 
$<\quad \alpha$ 0,05 maka dapat disimpulkan bahwa $\mathrm{H}_{0}$ ditolak dan Ha diterima yang berarti terdapat perbedaan pengaruh koordinasi mata-kaki tinggi dan koordinasi mata-kaki rendah terhadap kemampuan servis atas sepak takraw, (2) Perbedaan Pengaruh Antara Bola digantung dengan Bola dibuang Sendiri Terhadap Kemampuan Servis Atas Sepak Takraw. Berdasarkan hasil perhitungan diperoleh $-\mathrm{p}$ $0,006<\alpha 0,05$, maka dapat disimpulkan bahwa Ho ditolak dan $\mathrm{Ha}$ diterima yang berarti terdapat perbedaan pengaruh antara bola digantung dengan bola dibuang terhadap kemampuan servis atas sepak takraw, (3). Interaksi Antara Koordiansi Mata-kaki dengan Kemampuan Servis Atas Sepak Takraw. Berdasarkan hasil perhitungan diperoleh $-\mathrm{p} 0,009$ $<0,056$ 5, maka dapat disimpulkan bahwa Ho ditolak dan Ha diterima yang berarti terdapat Interaksi antara koordinasi mata-kaki dengan kemampuan servis atas sepak takraw. Nilai adjustd R Square sebesar 0,080 artinya bahwa terdapat interaksi sebesar $8 \%$.

Hasil perhitungan tentang hipotesis yang menyebutkan bahwa Terdapat perbedaan pengaruh antara koordinasi mata-kaki tinggi dan koordinasi mata-kaki rendah terhadap kemampuan servis atas sepak takraw pada mahasiswa PKO FIK-Unimed tahun 2017. Ada hubungan yang signifikan antara koordinasi mata-kaki dengan kemampuan servis atas sepak takraw ditunjukan $-\mathrm{p} 0,000<\alpha 0,05$.

Temuan dalam penelitian ini menjelaskan bahwa atlit yang memiliki koordinasi mata-kaki tinggi akan dapat melakukan servis atas sepak takraw lebih baik daripada yang memiliki koordinasi mata-kaki rendah. Mahasiswa yang memilki koordinasi mata-kaki tinggi akan memungkinkan mengkoordinasikan gerakan servis atyas sepak takraw lebih efektif dan efisien dan mampun mengarahkan bola ke sasaran yang diinginkan dengan baik. Dengan demikian dapat dikatakan bahwa koordinasi mata-kaki tinggi sangat diperlukan oleh setiap atlit sepak takraw. Berdasarkan hal tersebut maka setiap atlit perlu memiliki koordinasi matakaki yang tinggi untuk mendukung kemampuan servis atas sepak takraw.

Hasil perhitungan tentang hipotesis yang menyebutkan bahwa terdapat perbedaan pengaruh metode bola digantung dengan bola dibuang terhadap kemampuan servis atas sepak takraw pada mahasiswa PKO FIK-Unimed tahun 2017. Berdasarkan hasil yang diperoleh menunjukkan bahwa terdapat perbedaan pengaruh antara mwtode bola digantung dengan metode bola dibuang terhadap kemampuan servis atas sepak takraw $-\mathrm{p}$ $0,006<\alpha 0,05$. Dari hasil data menunjukkan bola dibuang sendiri lebih baik daripada bola digantung. Penyebabnya adalah pada metode bola dibuang sendiri memungkinkan mahsiswa bisa mengatur ketinggian bola yang diinginkan sehingga bola dapat disepak dengan baik. Selain itu, pada bola dibuang sendiri harus dibutuhkan kecepatan untuk bereaksi karena kalau tidak, maka bola akan turun dan sulit untuk dijangkau atau disepak dengan baik. Hal berbeda terjadi pada bola digantung, Karena bolanya tetap dan diam di udara maka mahasiswa lambat untuk melompat. Ini akan berpengaruh pada saat menerima bola yang bergerak yang menyebabkan kapan akan menyepak bola. Berbeda pada bola yang dibuang sendiri, karena bola bergerak maka sudah ada adaptasi dengan bola bergerak.

Hasil penelitian tentang hipotesis yang menyebutkan bahwa terdapat interaksi antara koordinasi mata-kaki dengan kemampuan servis atas sepak takraw -p 0,009 < 0,05. Dan nilai adjustd R Square sebesar 0,080 artinya bahwa terdapat interaksi sebesar $8 \%$.

Secara keseluruhan dapat dijelaskan bahwa setelah dilakukan pengujian secara statistik terhadap data empirik yang telah diperoleh dari lapangan dapat dikatakan bahwa variabel koordinasi matakaki yang diajukan memberikan interaksi terhadap kemampuan servis atas sepak takraw.

Tingkat koordinasi gerak seseorang merupakan cerminan dalam kemampuannya untuk melakukan suatu gerakan secara mulus, tepat dan efisien. Seorang dengan koordinasi yang baik bukan hanya mampu melakukan suatu keterampilan secara sempurna, tetapi juga mudah dan cepat dapat melakukan keterampilan gerak yang masih baru baginya. Dengan tingkat keterampilan yang baik seseorang dapat mengubah dan berpindah secara cepat dari pola gerak yang satu dengan yang lain, sehingga dengan memiliki tingkat koordinasi gerak yang baik, maka pola gerakan menjadi lebih efisien.

Dengan demikian maka dapat dijelaskan pentingnya memiliki koordinasi mata-kaki yang baik sehingga dapat meningkatkan kemampuan servis atas sepak takraw, artinya semakin baik koordinasi mata-kaki maka semakin baik kemampuan servis atas sepak takraw.. Sehingga bagi setiap atlit sepak takraw diharapkan untuk meningkatkan koordinasi mata-kaki untuk hasil servis atas yang bagus.

\section{KESIMPULAN}

Adapun kesimpulan penelitian ini yaitu: (1). Terdapat perbedaan pengaruh antara koordinasi mata-kaki tinggi dan koordinasi mata-kaki rendah terhadap kemampuan servis atas dalam permainan sepak takraw pada mahasisdwa PKO FIK Unimed tahun 2017, (2). Terdapat perbedaan pengaruh pembelajaran servis bola digantung dan bola dibuang sendiri terhadap kemampuan servis atas dalam permainan sepak takraw pada mahasiswa PKO FIK Unimed tahun 2017, (3). Terdapat interaksi antara metode pembelajaran servis atas sepak takraw dengan koordinasi mata-kaki pada mahasiswa PKOFIK Unimed tahun 2017. 
Peneliti dalam hal ini juga memberikan saran yakni: (1) guru hendaknya berusaha untuk meningkatkan kemampuannya dalam mengembangkan materi, menyampaikan materi, serta dalam mengelola kelas, sehingga kualitas pembelajaran yang dilakukannya dapat terus meningkat, (2). Dalam usaha meningkatkan kemampuan servis sepak takraw, selain penerapan metode pembelajaran yang tepat harus memperhatikan tingkat koordinasi mata-kaki mahasiswa, (3). Kepada guru dan pelatih diharapkan menerapkan model pembelajaran bola dilempar sendiri untuk meningkatkan kemampuan servis atas sepak takraw.

\section{REFERENSI}

Bompa O Tudor. 1994. Theory and Methodology of Training. Canada: Kendall/ Hunt Publishing Company.
Muhamad Suhud. 1991. Sepak Takraw. Jakarta: Balai Pustaka.

Ratinus Darwis dan Penghulu Basa.1992. Olahraga Pilihan Sepak Takraw. Jakarta: Departemen Pendidikan dan Kebudayaan Diretorat Jenderal pendidikan Tinggi Proyek Pembina Tenaga Pendidikan.

Sukadiyanto. 2002. Teori dan Metodologi Melatih Fisik. Yogyakarta: UNY

Sugiyanto.1993. Penelitian Pendidikan. Surakarta: Sebelas Maret UniversityPress.

Wiyaka, 2017. Sepak Takraw. Medan: FIK Unimed 